International Journal of Social Sciences and Humanities
Available online at http://sciencescholar.us/journal/index.php/ijssh
Vol.1 No. 3, December 2017, pages: 118 134
e-ISSN: 2550-7001, p-ISSN: 2550-701X
http://dx.doi.org/10.21744/ijssh.v1i3.65

\title{
Corporate Social Responsibility, Green Banking, and Going Concern on Banking Company in Indonesia Stock Exchange
}

I Gusti Ayu Agung Omika Dewi a I Gusti Ayu Agung Pradnya Dewi b
Article history: Received 12 July 2017 , Accepted in revised form 23 November 2017, Approved 8 December 2017
Available online 24 December 2017

a National Education University (UNDIKNAS) Denpasar, Indonesia omikadewi@undiknas.ac.id, ag.omikadewi@gmail.com

b National Education University (UNDIKNAS) Denpasar, Indonesia agungpradnya@undiknas.ac.id 
e-ISSN : 2550-7001, p-ISSN : 2550-701X@ Copyright 2017. The Author. SS Journals Published by Universidad Técnica de Manabí.

This is an open-access article under the CC BY-SA 4.0 license

(https://creativecommons.org/licenses/by-sa/4.0/)

All rights reserved.

\section{Contents}

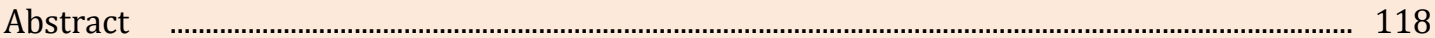

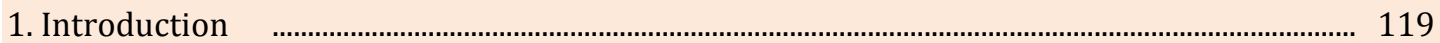

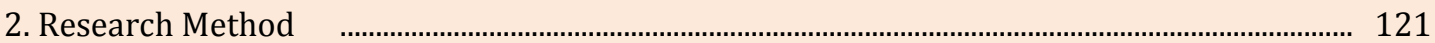

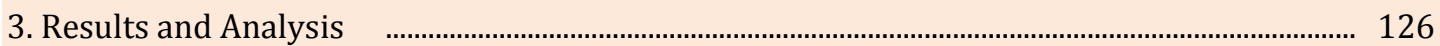

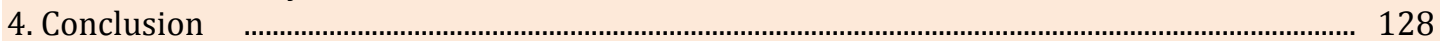

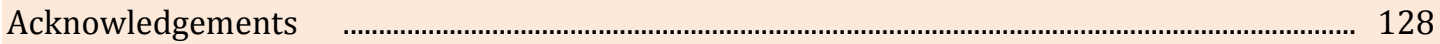

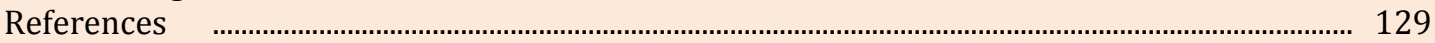

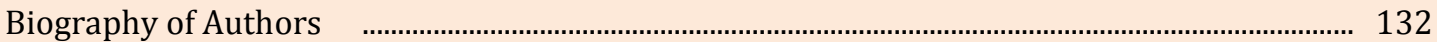

\section{Introduction}

The issue related to the social issues and the environmental issues are increasingly emerging among the international community, along with the emergence for various environmental crises, social crises, economic crises, energy and resource crises and other serious crises. ${ }^{1}$ The main cause of the environmental crisis that affects the disruption of the human social life, allegedly caused by the development strategies and policies that are not environmentally friendly and propeople. This strategy prioritizes the achievement of the economic interests without regard to the social and the environmental impacts caused by the economic activity. The environment and all the inherent natural resources are exploited and sacrificed by economic and business actors in order to realize massive economic growth and corporate profits. An increasingly strong drive from the international community has forced the Indonesian government to play an active role in the environmental issues. The Indonesia Government has formulated strategic and operational measures to further green Indonesia through sustainable development and green economy.

The bank is a financial institution that its main activity is collecting funds from the community and channeling the funds back to the community and providing services to other banks. ${ }^{11}$ An effort to realize the sustainable development based on the green economy, the banks have a strategic position to realize one part of the green economy concept that is green banking concept. The speech of the Deputy Governor of Bank Indonesia in the media briefing stated that the green banking policy is based on the vision of the national banking that must play an active role in the evolution of the sustainable development wherein the success indicators include the bank has an ability to provide of the efficient funding for development and the productive investment with regard to the principles of the environmental protection and management. The green banking defines the banking sector is no longer focused solely on the financial responsibility of managing its business as well as possible to generate maximum profit for shareholders, however, it is also to focus its responsibilities on the environmental conservation and the universe and improve the social welfare for the community large.

The concept of Green Banking is closely related to Corporate Social Responsibility (CSR) is the concept of corporate social responsibility and environment to stakeholders or parties affected by the existence of the company. The CSR can also be interpreted as an approach wherein companies integrate of the social concerns in their business operations and in interaction with stakeholders based on partnership and volunteer principles. ${ }^{21}$ For companies categorized as Limited Liability Companies/Perseroan Terbatas (PT) in Indonesia is no exception banking sector, the disclosure of Corporate Social Responsibility (CSR Disclosure) is an obligation set forth on the Law No. 40 in 2007. The CSR disclosure is conducted as an effort to realize

Dewi, I., \& Dewi, I. (2017). Corporate Social Responsibility, Green Banking, and Going Concern on Banking Company in Indonesia Stock Exchange. International Journal Of Social Sciences And Humanities (IJSSH), 1(3), 118-134. doi:10.21744/ijssh.v1i3.65 
transparency of the sustainable development based on triple bottom lines included economic, social, and environmental aspect. ${ }^{22}$

The claims of the stakeholders related to the CSR implementation is closely related to corporate goals to realize the Business Continuity (Going Concern). It is through the CSR implementation expected that the company will not only operate for the shareholders benefit, but also for the stakeholders benefit in business practices, i.e. workers, local communities, government, non-governmental organizations (NGOs), consumers, and the environment. ${ }^{23}$ Business Continuity (Going Concern) is an assumption that an entity will remain for business in the future. The entity will not be forced to discontinue operations and liquidate the assets in the near future. Going Concern will only be assured if the company takes into account the social and environmental dimensions. Indeed, the substance of the corporate social responsibility is in order to strengthen the sustainability of the company's own business by building cooperation among the stakeholders.

An amid various government efforts in dealing with these conflicts through nation-building, the Banking sector is considered to have an important role in restoring and maintaining the image of the Indonesian nation. The bank is a financial institution whose main activity is collecting funds from the community and channeling the funds back to the community and providing services for other banks. ${ }^{11}$ As an effort to realize sustainable development based on the green economy, the banking sector has a strategic position to realize one part of the green economy concept that is green banking concept.

The speech of the Deputy Governor, Bank Indonesia in the media briefing stated that the green banking policy is based on the vision of the national banking that must play an active role in the evolution of the sustainable development wherein the success indicators include the bank's ability to provide efficient funding for development and productive investment regarding the principles of the environmental protection and management. Green banking defines the banking sector is no longer focused solely on the financial responsibility of managing its business as well as possible to generate maximum profit for shareholders, but also in order to focus its responsibilities on the conservation of the environment and the universe and improve social welfare for the large community.

Green Banking is the main topic in the banking sector due to the banking sector is considered to have a strategic role in realizing the concept of Green Economy in the effort to overcome various social and environmental problems. The concept of Green Banking is closely related to Corporate Social Responsibility (CSR) as a form of accountability of the banking companies for Stakeholders in order to realize the banking sector that Going Concern. The CSR can also be interpreted as an approach wherein companies integrate social concerns in their business operations and in interaction with stakeholders based on partnership and volunteer principles. 24 For companies categorized as Limited Liability Companies/Perseroan Terbatas (PT) in Indonesia is no exception banking sector, the disclosure of Corporate Social Responsibility (CSR Disclosure) is an obligation set forth on the Law No. 40 in 2007. The CSR disclosure is conducted as an effort to realize transparency of the sustainable development based on triple bottom lines included economic, social, and environmental aspect. ${ }^{22}$

\section{Motivation Research}

This research is motivated by the fact that the research on Green Banking and CSR disclosure in relation to Going Concern on the company especially the banking sector is few conducted considering the issue of Green Banking is a new issue in the banking world. It found that the implementation of the CSR in PT Telkom Indonesia has been very good, which accounted 64\% for the business sustainability (Going Concern). ${ }^{25}$ Furthermore, the research conducted by 26 found that "Green Banking is a good way for awareness about sustainable development". Meanwhile, the study found that corporate characteristics, CSR influence, and CSR Disclosure. ${ }^{27}$ Departing from the thought then in this research will be tested the influence of Green Banking on 
the relationship between CSR and Going Concern banking companies in Indonesia Stock Exchange.

\section{Research question}

Based on the above description. It has been described then the formulation of the problem in this research are: Does the implementation of Green Banking have an effect on the relationship between Corporate Social Responsibility and Going Concern of Banking Companies in Indonesia Stock Exchange?

\section{Research purposes}

The purpose of the present study is to test and obtain empirical evidence on the influence of Green Banking implementation on the relationship between Corporate Social Responsibility and Going Concern of Banking Companies in Indonesia Stock Exchange.

\section{Research Method}

\subsection{Theoretical Framework}

\section{a. Theory of the Stakeholder}

The stakeholder theory states that a company is not an entity that only operates for its own interests but must provide benefits to its stakeholders. Thus, the existence of a company is strongly influenced by the support provided by stakeholders to the company. ${ }^{6}$ The corporate social responsibility should not be limited to generating maximum profit for the shareholder's benefit, but it should as well as take into account the interests for all parties who have a relationship or association with the company. The stakeholders are suppliers, customers, governments, local communities, employees, investors, political groups, and trade associations. ${ }^{27}$ According to ${ }^{28}$, the stakeholder's analysis included identification of the relevant stakeholders; identification of the stakeholder powers; and stakeholder coalitions. Based on Stakeholders theory, the companies should conduct stakeholder analysis, therefore, unlike to know what policies and actions will be taken by the company.

\section{b. Theory of the Legitimacy}

Legitimacy is a corporate management system oriented to the society alignment, government, individuals, and community groups. This theory stated that the organization is part of the community, therefore, it must pay attention to social norms of the society due to conformity with social norms can make the company more legitimate. ${ }^{29}$ It states that legitimacy can be obtained when there is a match between the existence of the company is not disturbing or congruent with the existence of the existing value system in society and environment. ${ }^{30}$ The theory of legitimacy becomes the foundation for the company to pay attention to what the community hopes and is able to align its corporate values with the prevailing social norms in place of the company is carrying out their activities.

If there is a shift leading to nonconformity, then the company's legitimacy can be threatened. Legitimacy is important to the organization, the limits emphasized by social norms and values, and reactions to those limits promote the importance of the organizational behavioral analysis regarding the environment. ${ }^{31}$ Based on the description above that the theory of legitimation is one of the theories underlying the disclosure of Corporate Social Responsibility, which aims to get positive and lethargic value from the community.

\section{c. Green Banking}

Green Banking is a business concept that refers to environmentally friendly business practices. In order to encourage banking corporations to grow and develop sustainably in an integrated economic, social and environmental dimension..$^{13}$ According to the Green Banking Green Banking Report (2014), Banking is not only focusing on financial responsibility to

Dewi, I., \& Dewi, I. (2017). Corporate Social Responsibility, Green Banking, and Going Concern on Banking Company in Indonesia Stock Exchange. International Journal Of Social Sciences And Humanities (IJSSH), 1(3), 118-134. doi:10.21744/ijssh.v1i3.65 
manage its business as well as possible to generate maximum profit for shareholders, but also to focus its responsibility on efforts preserve the environment (planet) and improve the social welfare of the people (people). The integration of the pillar is called Triple Bottom-Line of Banking accountability.

The integration main purpose is to ensure the long-term sustainability of profit and banking business. If the environment as the first pillar of the banking business is sustainable and the community as the second basic pillar is also well-maintained, then the implication is to corporate banking profit grows sustainably. The sustainability of the three pillars will certainly result in long-term growth and business sustainability. Some important things from green banking activities are:

1. The bank can help the environment through automation and online banking.

2. Green banking focuses on safety and social security through changes in negative impacts in the community.

3. On the funding side always prioritize investments or loans by considering risk factors regarding environmental conditions.

4. It always cares about sustainable growth and environmentally friendly in the industry and for the social purposes.

5. Creating a suitable atmosphere inside and outside the bank.

6. Assuming clients unlike their family members, guide, and advice on projects to reduce pollution levels by implementing a scientific methodology in real life by implementing the Environmental Due Diligent (EDD) list.

7. Reducing costs and energy by saving funds and increasing GDP of a State.

\section{d. Corporate Social Responsibility}

CSR is the responsibility of the company against actions affecting people, communities, and the environment in general. ${ }^{33}$ Corporate Social Responsibility is a sustainability commitment to give positive impact to the environment and society where the company is, in addition, being in business activities, in order to balance corporate responsibility in generating profit but also beneficial for society and environment. ${ }^{34}$ CSR implementation by the company is then reported through CSR disclosure social responsibility accounting mechanism published through annual report or separate social report in the form of sustainability report.

The guidelines used as a reference in CSR disclosure is a guideline of the Global Reporting Initiative (GRI). CSR disclosure categories by GRI 4.0 standards that were launched in May 2013. It uses standards consisting of the three focuses on economic, environmental, and social disclosure as the basis for sustainability reporting. In GRI consists of the several performance indicators, including Financial, Environment, Labor, Human Rights, Social, and Product. In the indicator, there are categories of 91 items or categories (economy 9 categories, environment 34 categories, labor 16 categories, society/community 11 categories, human rights 12 categories, and products 9 categories).

\section{e. Going Concern}

The going concern assumption defines a business entity is deemed to be able to sustain its business activities in the long term and not be liquidated in the short term. Going Concern is a condition wherein the company can remain operational in the long term to the future, which is influenced by financial and non-financial circumstances. ${ }^{33}$ Whereas, Going Concern is the survival of a business entity with a going concern then a business entity is considered will be able to maintain its efforts in the long term..$^{34}$

Going Concern is closely related to sustainable development. The sustainability development arises from the world's concern for economic growth through rapid industrialization that directly or indirectly damages the environment, especially, pollution or pollution impacts. It was introduced by one of the UN organizations in 1987 through the 
Brundtland commission with the definition of "development that meets the needs of the present generations to meet their own needs". ${ }^{15}$ It is implemented of the concept of green economy defines a development model to prevent increasing greenhouse gas emissions and address climate change.

One of the company's efforts to keep the company going concern in accordance with the concept of the sustainable development is to implement CSR. Through the implementation, the CSR expected the desire of stakeholders can be accommodated, therefore, it will produce a harmonious relationship between the company and its stakeholders. The harmonious relationship will obtain thus company can achieve business continuity (going concern) or sustainability of the company (sustainability).

\section{f. Definition of Bank}

The bank is an institution that acts as a financial intermediary between the party who owns the fund and the party who needs the funds, and as a functioning institution to meet the traffic cross payment. ${ }^{9}$ The bank is a financial institution whose main activity is collecting funds from the community and channeling the funds back to the community as well as providing the services for other banks. ${ }^{11}$ It can be concluded that the Bank is a financial institution whose activities collect funds from the public in the form of the demand deposits, savings deposits, and deposits, then the channel funds to the community in the form of loans (credit), and provide other services that include deposit services, payment services, transfer, clearing, forex, safe deposit box, travelers check, Bankcard.

The main objectives and function of the bank establishment in Indonesia as Financial Intermediary and also as Agent of Development (especially for state-owned banks). If it is viewed from its function as a Financial Intermediary, the bank serves as an intermediary for the collection of funds from the community and the fund's distribution to the public. Meanwhile, the Bank function as Agent Of Development is the keeper of the monetary stability in Indonesia. This function can be seen in two crediting programs, namely KIK (Small Investment Credit) and KMKP (Permanent Working Capital Credit). The benefits derived from banking services according to its function as working balance, investment fund and saving purpose. Working balance is to support daily business transaction procedures thus facilitate the process of receiving and disbursement of the transaction payments. An investment fund is an investment place of the idle fund with the expectation of obtaining interest. Saving purpose, aimed at the security of funds, both physically (theft) is also morally (inflation, devaluation, and depreciation)

\subsection{Previous Research Results}

Some previous research that used as a reference in the present study is presented in Table 1 in the following:

Table 1

Previous Research Results

\begin{tabular}{cll}
\hline No & \multicolumn{1}{c}{ Tittle and Authors } & \multicolumn{1}{c}{ Empirical Research Results } \\
\hline 1. & $\begin{array}{l}\text { Pengaruh Pertanggungjawaban Sosial } \\
\text { Perusahaan (Corporate Social Responsibility) } \\
\text { Terhadap keberlanjutan Usaha Perusahaan (Case } \\
\text { Study PT. Telkom) : Dani Ali Hamdani (2013) }\end{array}$ & $\begin{array}{l}\text { Pertanggungjawaban Sosial Perusahaan } \\
\text { (Corporate Social Responsibility) berpengaruh } \\
\text { positif signifikan terhadap Keberlanjutan Usaha } \\
\text { (Going Concern) PT. Telkom about 64\% }\end{array}$ \\
\hline 2. & $\begin{array}{l}\text { Study Of Green Banking Trends in India (An } \\
\text { Qualitative Research) : Nishikant Jha And } \\
\text { Shraddha Bhome (2013) }\end{array}$ & $\begin{array}{l}\text { Green banking is good way for awareness about } \\
\text { sustainable development (Green Banking adalah } \\
\text { cara yang baik dalam mendukung terwujudnya }\end{array}$ \\
\hline
\end{tabular}

Dewi, I., \& Dewi, I. (2017). Corporate Social Responsibility, Green Banking, and Going Concern on Banking Company in Indonesia Stock Exchange. International Journal Of Social Sciences And Humanities (IJSSH), 1(3), 118-134. doi:10.21744/ijssh.v1i3.65 
pembangunan berkelanjutan)

3. Pengaruh Karakteristik Perusahaan dan

Tanggung Jawab Lingkungan pada

Pengungkapan Tanggung Jawab Sosial

Perusahaan : Ni Wayan Oktariani and Putu Sri

Harta Mimba (2014)
Hutang, Profitabilitas, dan Tanggung Jawab Lingkungan berpengaruh positif terhadap Pengungkapan Tanggung Jawab Sosial Perusahaan (Corporate Social Responsibility Disclosure)

Source: Data Processed

\subsection{Research model}

The research model was designed at aiming for making easier to identify and solve the problems. The research model can be illustrated as follows:

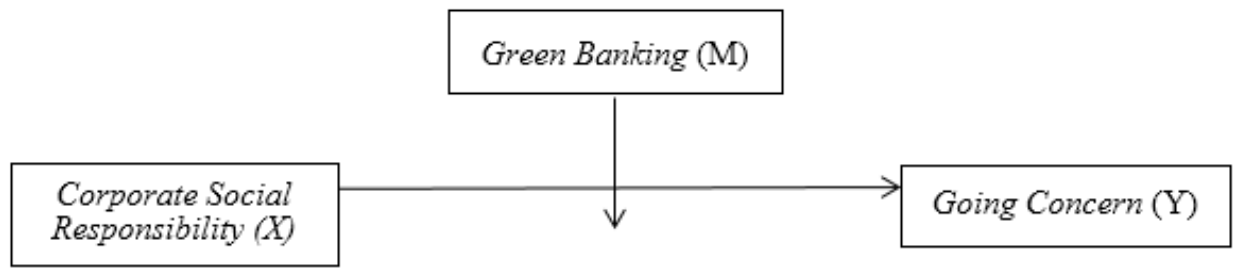

Chart 1

\subsection{Research Hypothesis}

The concept of Green Banking is closely related to Corporate Social Responsibility (CSR) which is the concept of the corporate social responsibility and environment to stakeholders in the effort to realize Going Concern. The implementation of CSR is conducted as an effort to realize transparency of the sustainable development in order to realize Going Concern wherein the banking sector. This relationship can be moderated by the implementation of Green Banking. Based on the above description can be formulated research hypothesis as follows:

H1: Going Concern affects towards relationship between Corporate Social Responsibility and Going Concern

\subsection{Location and Research Periods}

The study was conducted at a banking company listed on the Indonesia Stock Exchange in 2013 to 2015 period. The data is obtained by accessing the official website of the Indonesia Stock Exchange (http://www.idx.co.id)

\subsection{Determination of Data Sources and Data Types}

The data sources that are used in the present study is a secondary data obtained from the Indonesia Stock Exchange in the form of Annual Report and Sustainability Report of Banking Companies from 2013 to 2015 through the official website of National Center for Sustainability Reporting i.e. www.sra.ncsr-id.org. This study uses a quantitative data type derived from annual reports of banking companies in 2013-2015 listed on the Indonesia Stock Exchange as well as sustainability reports taken from participants of the sustainability reporting award from the National Center for Sustainability Reporting.

\subsection{Population and Sample Research}

The population that is used in the present study is a banking company listed on the Indonesia Stock Exchange (BEI). The method of sampling collection is used a purposive sampling method with some criteria as follows: 
1. Conventional banking sector (non-shariah) listed on Indonesia Stock Exchange.

2. The banking sector that publishes and publishes annual reports for the 2013-2015 period.

3. The banking sector that publishes a sustainability report in 2013-2015.

4. Displaying data and information relating to green banking in relation affect the relationship between CSR and the bank's going concern.

Table 2

The list of sample companies names on banking sector in 2013-2015

\begin{tabular}{clc}
\hline No & \multicolumn{1}{c}{ Company Name } & Issuer \\
\hline 1 & Bank Negara Indonesia & BBNI \\
\hline 2 & Bank Mandiri & BMRI \\
\hline 3 & Bank Rakyat Indonesia & BBRI \\
\hline 4 & Bank Tabungan Negara & BBTN \\
\hline 5 & Bank Permata & BNLI \\
\hline 6 & Bank CIMB Niaga & BNGA \\
\hline 7 & Bank Danamon & BDMN \\
\hline 8 & Bank Maybank Indonesia & BNII \\
\hline 9 & Bank Pembangunan Daerah Jatim & BJTM \\
\hline 10 & Bank Jabar Banten &
\end{tabular}

\subsection{Technique of Data Collection}

The technique of collecting the data used in the present study is through documentation study, which is conducted by searching, collecting, recording, and review data on things or variables in the form of notes, documents, transcripts, books, newspapers, magazines, journals, websites and etc. It is intended to collect the overall data needed to answer the research problem and enrich the literature to support the quantitative data obtained.

\subsection{Research variable}

a. Independent Variables

Independent variable in the present research is CSR Disclosure. CSR Disclosure is measured using Corporate Social Responsibility Index (CSRI). The CSRI calculations based on the criteria of the Global Reporting Initiative (GRI) 4.0 obtained from www.globalreporting.org amount 91 items of disclosure criteria. The calculation of CSRI is conducted by using a dichotomy approach, i.e. each CSR item in the research instrument is given 1 value if it is disclosed and 0 value if it is not disclosed. Furthermore, the score of each item summed to obtain the overall score for each company calculation formula CSRI as follows:

$$
\text { CSRDIj }=\frac{\sum X i j}{n j}
$$

Description:

CSRDIj : Corporate Social Responsibility Index

nj $\quad$ : number of items for company j, nj $\leq 91$.

$\mathrm{Xij} \quad: 1=$ if item $\mathrm{I}$ is disclosed; $0=$ if item is not disclosed

Dewi, I., \& Dewi, I. (2017). Corporate Social Responsibility, Green Banking, and Going Concern on Banking Company in Indonesia Stock Exchange. International Journal Of Social Sciences And Humanities (IJSSH), 1(3), 118-134. doi:10.21744/ijssh.v1i3.65 
b. Dependent Variables

The dependent variable in the present research is Business Continuity (Going Concern). Going Concern is an assumption that an entity will remain in the business in the future and will not be liquidated in the short term. Going concern value is measured by using Price book Value ratio. This ratio measures the value that financial markets give to management and corporate organizations as a growing company. The formula used to calculate the PBV ratio is as follows:

$$
\mathrm{PBV}=\frac{\text { Stock price }}{\text { total asset-intangible assets and liabilities }}
$$

c. Moderation Variables

Moderation variable in the present research is Green Banking. It is variable that strengthen or weaken the relationship between dependent variable and independent variable. ${ }^{18}$ The implementation of Green Banking is shown through the disclosure in the Annual Report and Sustainability Report whether or not it has implemented the Green Banking implementation. It is done by using Dummy variable, if it has implemented Green Banking then given the point 1 , if not then given the point 0 .

\section{Results and Analysis}

\subsection{Data analysis}

The data in this study is analyzed with descriptive statistics, then tested the coefficient of determination and hypothesis testing. The descriptive statistics provide an overview of the frequency distribution of the research variables, maximum values, minimum, mean, and standard deviations. The data analysis using interaction test or Moderated Regression Analysis (MRA).

\subsection{Test of Determination Coefficient}

The measurement of the determination coefficient is conducted to know the percentage of the influence of independent variables on the change of the dependent variables, which is explained by other causes outside the model. ${ }^{6}$ In order to test how far the research model in explaining the dependent variable (good of fit), that is by calculating the coefficient of determination (adjusted R2). The greater of the adjusted R2 for the independent variable, the more dominant the influence of independent variables on the dependent variable.

The $\mathrm{R} 2$ value that has been adjusted between zero and up to one. The R2 value adjusted is approaching one means that the ability of the independent variables gives almost all the information needed to predict the dependent variable. ${ }^{34}$ The R2 value Adjusted is small or below 0.5 means the ability of the independent variables in explaining the dependent variable is very small. If any value $\mathrm{R} 2$ adjusted is negative, then, it is considered zero. ${ }^{6}$

\subsection{Moderated Regression Analysis (Interaction Test)}

Moderated Regression Analysis (MRA) or interaction test is a special application of the linear multiple regression wherein the regression equation consists of the interaction element (multiplication of two or more independent variables) with equation formula as follows:

$$
\mathrm{Y}=\alpha+\beta 1 . \mathrm{X} 1+\beta 2 \mathrm{X} 1 . \mathrm{X} 2+\mathrm{e}
$$

Description:

$\mathrm{Y} \quad=$ Going Concern

$\alpha \quad=$ Constant

$\beta 1, \beta 2=$ Regression coefficients 
$\mathrm{X} 1=\mathrm{CSR}$

$\mathrm{X} 2=$ Green Banking

e $\quad=$ error term, i.e. the error rate of the estimator in the study

\subsection{Description of Research Variables}

The descriptive statistics in the study are presented in Table 2, as follows:

Tabel 3

Descriptive Statistics

\begin{tabular}{|l|r|r|r|r|r|}
\hline & $\mathrm{N}$ & Minimum & Maximum & \multicolumn{1}{c|}{ Mean } & Std. Dev iation \\
\hline $\mathrm{X}$ & 30 &, 26 &, 71 &, 4654 &, 12010 \\
$\mathrm{M}$ & 30 &, 00 & 1,00 &, 7333 &, 44978 \\
$\mathrm{Y}$ & 30 &, 22 & 1,36 &, 8597 &, 34802 \\
Valid N (listwise) & 30 & & & & \\
\hline
\end{tabular}

Source: Data processed, 2017

The Descriptive Statistics aims at providing information on the characteristics of the research variables, including minimum, maximum, mean, and standard deviation. The mean measurements are the most commonly used means of measuring the central value of the data distribution. Whereas, the standard deviation is the difference of the value of the data studied with the average value. Based on Table 3. above can be seen the minimum value for CSR (X) is 0.26 and the maximum value is 0.71 . The mean for CSR is 0.4564 , with a standard deviation is 0.10. For the Green Banking variable (M) the minimum value is 0.00 and the maximum value is 1.00. While, Mean for Green Banking is 0.73333 , with a standard deviation of 0.44978. For the variable Going Concern (Y) the minimum value is 0.22 and the maximum value is 1.36 . and the mean variable Going Concern is 0.8597 , with the standard deviation is 0.34802 .

\subsection{Regression Analysis with Moderating Variables}

The result of regression analysis with Moderate Variables presented in Table 4, as follows:

Table 4

Regression Analysis with Moderation Variables

\begin{tabular}{|c|c|c|c|c|c|c|}
\hline & \multirow[t]{2}{*}{ Model } & \multicolumn{2}{|c|}{$\begin{array}{l}\text { Unstandardized } \\
\text { Coeficients }\end{array}$} & \multirow{2}{*}{$\begin{array}{c}\text { Standardized } \\
\text { Beta } \\
\end{array}$} & \multirow[b]{2}{*}{$\mathrm{T}$} & \multirow[b]{2}{*}{ Sig. } \\
\hline & & $\mathrm{B}$ & Std.Error & & & \\
\hline \multirow[t]{6}{*}{1} & (Constant) & 0,52 & 0,83 & 0,000 & 0,634 & 0,532 \\
\hline & $\mathrm{X}_{1}$ & 0,702 & 0,195 & 0,242 & 3,594 & 0,001 \\
\hline & $\mathrm{X}_{1} \mathrm{X}_{2}$ & 0,494 & 0,228 & 0,340 & 2,168 & 0,039 \\
\hline & Adjusted $\left(\mathrm{R}^{2}\right)$ & & & 0,968 & & \\
\hline & F Hitung & & & 293,013 & & \\
\hline & Signifikansi F & & & 0,000 & & \\
\hline
\end{tabular}

Source: Data processed (2017)

Based on Table 4 can be seen Goodness of Fit from the results of the regression analysis with moderating variables as follows:

a. Regression Equation

Based on the data listed in Table 4, the regression equation is obtained, as follows:

Dewi, I., \& Dewi, I. (2017). Corporate Social Responsibility, Green Banking, and Going Concern on Banking Company in Indonesia Stock Exchange. International Journal Of Social Sciences And Humanities (IJSSH), 1(3), 118-134. doi:10.21744/ijssh.v1i3.65 


$$
\mathrm{Y}=0,52+0,702 \cdot \mathrm{X} 1+0,494 \mathrm{X} 1 \cdot \mathrm{X} 2+\mathrm{e}
$$

b. Model Feasibility Test (F Test)

Based on Table 4, it can be seen that the significance of $F$ is smaller than $\alpha(0,000$ $<0.05$ ) therefore, it can be concluded that the model used in the study is feasible (Fit).

c. Hypothesis Test (t-test)

The moderate implementation of Green Banking on the relationship between Corporate Social Responsibility and Going Concern. Based on Table 4, it can be seen that the significance of the interaction variable $\mathrm{X}_{1} \mathrm{X}_{2}$ is smaller than $\alpha(0.039<0.05)$ therefore, it can be concluded that the implementation of Green Banking strengthens the relationship between Corporate Social Responsibility and Going Concern of Banking companies in Indonesia Stock Exchange. The results obtained support the hypothesis that has been made. If the Banking Company in Indonesia Stock Exchange has implemented Green Banking as stipulated in its Corporate Social Responsibility implementation and disclosed in the annual report and sustainability report, the banking company's Going Concern can be assured in the future.

d. Coefficient of Determination $\left(\mathrm{R}^{2}\right)$

Based on Table 4, it can be seen that Adjusted $\left(\mathrm{R}^{2}\right)$ obtained is 0.968 therefore, it can be concluded that $96,8 \%$ variable of Going Concern can be explained by Corporate Social Responsibility which moderated by Green Banking, while the rest equal is $13,2 \%$ explained by variable others not found in the research model.

\section{Conclusion}

Based on the research results on the implementation of Green Banking, Corporate Social Responsibility, and Going Concern Banking Companies in Indonesia Stock Exchange. It can be concluded that Green Banking can strengthen the relationship between Corporate Social Responsibility and Going Concern Banking Companies in Indonesia Stock Exchange.

\section{Research Implication}

Theoretically, the results of the present study are expected to provide a deeper picture and understanding of the impact of Green Banking implementation on the relationship between Corporate Social Responsibility and Going Concern of Banking Companies in Indonesia Stock Exchange. The results of this study are also expected to be used as reference material for further research. Practically, the results of this study are expected to assist the management in the banking sector in implementing Green Banking related to CSR and Going Concern banking companies, as well as consideration for stakeholders in the banking sector in decision-making.

\section{Research Limitation}

Green Banking variables as moderating variables tend to be still not widely used in accounting research, therefore, the size is still not too clear.

\section{Suggestions}

The suggestions for the further researcher in order to find another alternative to measure Green Banking variables, or use other variables as a moderator for further research can be more varied.

\section{Acknowledgements}

Our deep and sincere gratitude were presented to God for having granted us the ability and the opportunity to complete this paper. As well as, we have much appreciated to our friends for their support, suggestion, contribution in finishing this research. We would like thanking I Wayan Suryasa that has given us a good advisement. Last but not least, we dedicated our dreadful thank my friend who those as editor in ScienceScholar, who has reviewed and approved this study to be published. 


\section{References}

1. Brigham, E. F., \& Houston, J. F. (2001). Manajemen Keuangan. Buku 1 edisi 8. Jakarta: Erlangga.

View in (Google Scholar)

2. Courtis, J. K. (1976). Relationships between timeliness in corporate reporting and corporate attributes. Accounting and Business Research, 7(25), 45-56.

View in (Google Scholar) (Scopus)

3. Dahya, J., McConnell, J. J., \& Travlos, N. G. (2002). The Cadbury committee, corporate performance, and top management turnover. The Journal of Finance, 57(1), 461-483.

View in (Google Scholar) (Scopus)

4. Dye, R. A., \& Sridhar, S. S. (1995). Industry-wide disclosure dynamics. Journal of accounting research, 157-174.

View in (Google Scholar) (Scopus)

5. Fama, E. F., \& Jensen, M. C. (1983). Separation of ownership and control. The journal of law and Economics, 26(2), 301-325.

View in (Google Scholar) (Scopus)

6. Ghozali, Imam, 2005. Aplikasi Analisis Multivariate dengan Program SPSS, Badan Penerbit Universitas Diponegoro, Edisi 13.

View in (Google Scholar) (Scopus)

7. Gujarati, D. N., \& Porter, D. C. (2003). Basic Econometrics. 4th.

View in (Google Scholar) (Scopus)

8. BPFE, U. (2007). Metodologi Penelitian Bisnis: Salah Kaprah Dan Pengalaman-Pengalaman. View in (Google Scholar)

9. Murdoko Sudarmadji, A., \& Sularto, L. (2007, August). Pengaruh ukuran perusahaan, profitabilitas, leverage, dan tipe kepemilikan perusahaan terhadap luas voluntary disclosure laporan keuangan tahunan. In Seminar Ilmiah Nasional PESAT 2007. Lembaga Penelitian Universitas Gunadarma.

View in (Google Scholar)

10.Jensen, M. C., \& Meckling, W. H. (1976). Theory of the firm: Managerial behavior, agency costs and ownership structure. Journal of financial economics, 3(4), 305-360.

View in (Google Scholar) (Scopus)

11. Kasmir, 2013. Bank dan lembaga Keuangan lainnya, Jakarta.PT Raja Grafindo Persada View in (Google Scholar) (Scopus) (Elsevier)

12. Anggadini, S. D. (2010). Analisis Fee Based Income Dampaknya terhadap Profitabilitas (Studi Kasus pada PT. Bank Negara Indonesia (Persero), Tbk.

View in (Google Scholar)

13.EMAS, P. P. P., \& WARDHANI, H. F. ANALISIS PENGARUH KINERJA LINGKUNGAN DAN KINERJA KEUANGAN TERHADAP KINERJA SAHAM PADA.

View in (Google Scholar)

Dewi, I., \& Dewi, I. (2017). Corporate Social Responsibility, Green Banking, and Going Concern on Banking Company in Indonesia Stock Exchange. International Journal Of Social Sciences And Humanities (IJSSH), 1(3), 118-134. doi:10.21744/ijssh.v1i3.65 
14.Hanafi, M. M., \& Halim, A. (2007). Analisis laporan keuangan. Yogyakarta: UPP STIM YKPN. View in (Google Scholar)

15.Akmalia, N. (2017). Pengaruh Stakeholders Power, Ukuran Perusahaan, Kinerja Lingkungan Dan Eksposur Media Terhadap Pengungkapan Lingkungan (Bachelor's thesis, Jakarta: Fakultas Ekonomi dan Bisnis UIN Syarif Hidayatullah Jakarta).

View in (Google Scholar)

16.Putranto, Y. A., \& Kewal, S. S. (2017). Pengaruh Corporate Social Responsibility Berbasiskan Karakteristik Social Bank Terhadap Kinerja Perusahaan Perbankan Di Bursa Efek Indonesia. Universitas Tarumanagara Journal of Accounting, 18(3).

View in (Google Scholar)

17.Solihin Ismail.2015.Corporate Social Responsibility from Charity to Sustainability.Jakarta: Salemba Empat.

View in (Google Scholar)

18. Puspitasari, K. D., \& Latrini, M. Y. (2014). Pengaruh Ukuran Perusahaan, Anak Perusahaan, Leverage dan Ukuran KAP terhadap Audit Delay. E-Jurnal Akuntansi, 8(2), 283-299.

View in (Google Scholar)

19.Trisnawati Rina.2014.Pengaruh Ukuran Perusahaan Profitabilitas Leverage UkuranDewan Komisaris dan Kepemilikan Manajerial Terhadap Pengungkapan CSR.Seminar Nasional dan call for paper Progdi Akuntansi FEB UMS ,Juni 2014.

View in (Google Scholar)

20.Wardhani, R. S. (2013). Pengaruh CSR Disclosure Terhadap Nilai Perusahaan Dengan Kinerja Keuangan Sebagai Variabel Intervening (Studi Kasus Perusahaan Manufaktur Yang Terdaftar di BEI).

View in (Google Scholar)

21. Mardika, I. N. (2017). The opposition of Community Citizenship Against the Policy of the Village's Leader. International Journal of Social Sciences and Humanities (IJSSH), 1(3), 74-87.

View in (Google Scholar) (Elsevier)

22.Jain, P. (2017). Cashless System of Colleges in India. International Journal of Social Sciences and Humanities (IJSSH), 1(3), 1-7.

View in (Google Scholar) (Elsevier)

23.Larantika, A. A. A. D., Zauhar, S., Makmur, M., \& Setyowati, E. (2017). Collaboration as a Strategy for Poverty Alleviation. International Journal of Social Sciences and Humanities (IJSSH), 1(3), 40-48.

View in (Google Scholar) (Elsevier)

24.Adetunji, A. T., Adetunji, A. V., Adeleke, E. O., \& Madubuike, S. C. (2017). Deregulation: The Effect of Market-led Approach to Nigerian Universities Management. International Journal of Social Sciences and Humanities (IJSSH), 1(1), 1-8.

View in (Google Scholar) (Elsevier) 
25. Martini, I. A. O., Lasmi, N. W., Jaya, N. K., \& Sutrisni, N. K. E. (2017). Improving Cooperative Performance through Human Resource Development Efforts. International Journal of Social Sciences and Humanities (IJSSH), 1(3), 49-58.

View in (Google Scholar) (Elsevier)

26.Pemayun, A. G. P., \& Maheswari, A. I. A. (2017). Economic Impacts of Craftsman Statue on Community Based Tourism Development. International Journal of Social Sciences and Humanities (IJSSH), 1(3), 59-73.

View in (Google Scholar) (Elsevier)

27.Alcivar, M. S. G., Pérez, A. V., Gilert, B. I. C., \& Gámez, M. R. (2017). Zeolite in Wastewater Decontamination as a Local Development Solution. International Journal of Life Sciences (IJLS), 1(3), 1-13.

View in (Google Scholar) (Elsevier)

28.Cheng, B., Ioannou, I., \& Serafeim, G. (2014). Corporate social responsibility and access to finance. Strategic Management Journal, 35(1), 1-23.

View in (Google Scholar) (Scopus)

29.Claessens, S., \& Yurtoglu, B. B. (2013). Corporate governance in emerging markets: A survey. Emerging markets review, 15, 1-33.

View in (Google Scholar) (Scopus)

30.Konar, S., \& Cohen, M. A. (2001). Does the market value environmental performance?. The review of economics and statistics, 83(2), 281-289.

View in (Google Scholar) (Scopus)

31.Tang, L., \& Li, H. (2009). Corporate social responsibility communication of Chinese and global corporations in China. Public Relations Review, 35(3), 199-212.

View in (Google Scholar) (Scopus)

32. Belal, A. R., \& Momin, M. (2009). Corporate social reporting (CSR) in emerging economies: A review and future direction. Research in accounting in emerging economies, 9(1), 119-143.

View in (Google Scholar) (Scopus)

33. McDonald, K., Bosshard, P., \& Brewer, N. (2009). Exporting dams: China's hydropower industry goes global. Journal of environmental management, 90, S294-S302.

View in (Google Scholar) (Scopus)

34.Margolis, J. D., Elfenbein, H. A., \& Walsh, J. P. (2009). Does it pay to be good... and does it matter? A meta-analysis of the relationship between corporate social and financial performance.

View in (Google Scholar) (Scopus)

Dewi, I., \& Dewi, I. (2017). Corporate Social Responsibility, Green Banking, and Going Concern on Banking Company in Indonesia Stock Exchange. International Journal Of Social Sciences And Humanities (IJSSH), 1(3), 118-134. doi:10.21744/ijssh.v1i3.65 


\section{Biography of Author}

\begin{tabular}{|l|l|}
\hline I Gusti Ayu Agung Omika Dewi, SE., MSA., AK., CA. is a senior lecturer at \\
Undiknas University. Her email address is omikadewi@undiknas.ac.id and a \\
civil servant. She is interested in accounting studies. She finished her \\
Bachelor Degree in accounting at Udayana University, Denpasar, Bali- \\
Indonesia. She completed her Master Degree at Brawijaya University, \\
Malang-Indonesia in 2010. He had chartered accountant No. 11. D40670 for \\
CA degree from IAI (Indonesian Accountant Association) since August 26th, \\
2014. She taught some subjects included corporate social responsibility, \\
contemporary financial accounting, introduction of accounting I \& II, \\
management information system, accounting information system.
\end{tabular}


APPENDIX

Descriptive

Descriptive Statistics

\begin{tabular}{|l|r|r|r|r|r|}
\hline & \multicolumn{1}{|c|}{$\mathrm{N}$} & \multicolumn{1}{|c|}{ Minimum } & Maximum & \multicolumn{1}{c|}{ Mean } & Std. Deviation \\
\hline $\mathrm{X}$ & 30 &, 26 &, 71 &, 4654 &, 12010 \\
$\mathrm{M}$ & 30 &, 00 & 1,00 &, 7333 &, 44978 \\
$\mathrm{Y}$ & 30 &, 22 & 1,36 &, 8597 &, 34802 \\
Valid N (listwise) & 30 & & & & \\
\hline
\end{tabular}

Regression

Variables Entered/Removed

\begin{tabular}{|l|l|l|l|}
\hline Model & $\begin{array}{c}\text { Variables } \\
\text { Entered }\end{array}$ & $\begin{array}{c}\text { Variables } \\
\text { Removed }\end{array}$ & Method \\
\hline 1 & $\mathrm{X}^{\mathrm{a}}$ & & Enter \\
\hline
\end{tabular}

a. All requested $v$ ariables entered.

b. Dependent Variable: $Y$

Model Summary

\begin{tabular}{|l|r|r|r|r|}
\hline Model & \multicolumn{1}{|c|}{$\mathrm{R}$} & R Square & $\begin{array}{c}\text { Adjusted } \\
\text { R Square }\end{array}$ & $\begin{array}{r}\text { Std. Error of } \\
\text { the Estimate }\end{array}$ \\
\hline 1 &, $604^{\mathrm{a}}$ &, 365 &, 343 &, 28217 \\
\hline
\end{tabular}

a. Predictors: (Constant), $\mathrm{X}$

\begin{tabular}{|c|c|c|c|c|c|c|}
\hline \multicolumn{7}{|c|}{ ANOVA } \\
\hline Model & & $\begin{array}{l}\text { Sum of } \\
\text { Squares }\end{array}$ & df & Mean Square & $\mathrm{F}$ & Sig. \\
\hline 1 & Regression & 1,283 & 1 & 1,283 & 16,114 &, $000^{\mathrm{a}}$ \\
\hline & Residual & 2,229 & 28 & ,080 & & \\
\hline & Total & 3,512 & 29 & & & \\
\hline
\end{tabular}

a. Predictors: (Constant), $\mathrm{X}$

b. Dependent Variable: $Y$

Dewi, I., \& Dewi, I. (2017). Corporate Social Responsibility, Green Banking, and Going Concern on Banking Company in Indonesia Stock Exchange. International Journal Of Social Sciences And Humanities (IJSSH), 1(3), 118-134. doi:10.21744/ijssh.v1i3.65 


\section{Coefficients $^{\mathrm{a}}$}

\begin{tabular}{|c|c|c|c|c|c|c|}
\hline \multirow{2}{*}{\multicolumn{2}{|c|}{ Model }} & \multicolumn{2}{|c|}{$\begin{array}{l}\text { Unstandardized } \\
\text { Coefficients }\end{array}$} & \multirow{2}{*}{$\begin{array}{c}\text { Standardized } \\
\text { Coefficients } \\
\text { Beta } \\
\end{array}$} & \multirow[b]{2}{*}{$t$} & \multirow[b]{2}{*}{ Sig. } \\
\hline & & $\mathrm{B}$ & Std. Error & & & \\
\hline & (Constant) & ,045 & 209 & & ,213 & ,833 \\
\hline & $x$ & 1,751 & ,436 & ,604 & 4,014 & ,000 \\
\hline
\end{tabular}

a. Dependent Variable: $Y$

Regression

\section{Variables Entered/Removed}

\begin{tabular}{|l|c|c|c|}
\hline Model & $\begin{array}{c}\text { Variables } \\
\text { Entered }\end{array}$ & $\begin{array}{c}\text { Variables } \\
\text { Removed }\end{array}$ & Method \\
\hline 1 & $\mathrm{XM}, \mathrm{X}, \mathrm{M}$ & & Enter \\
\hline
\end{tabular}

a. All requested $v$ ariables entered.

b. Dependent Variable: $Y$ 